\title{
Contractor Selection for Construction Works in Ghana: Towards Policy and Practice
}

\author{
Mohammed Awal Sidik ${ }^{1}$, Adamu Ibrahim², Bondinuba, F.K. ${ }^{3}$, F.D.K. Fugar ${ }^{4}$ \\ ${ }^{1,2}$ Department of Building Technology and Estate Management, School of Applied Science and Technology \\ Wa Technical University, P.O.Box 553, Wa-Ghana. \\ Email: ${ }^{1}$ sidikawal@yahoo.co.uk._2aiminis75@yahoo.com \\ ${ }^{3}$ Department of Building Technology, Faculty of Built and Natural Environment \\ Kumasi Technical University, P. O. Box 854, Kumasi-Ghana. \\ Email: francis.kbondinuba@kstu.edu.gh. \\ ${ }^{4}$ Department of Building Technology, KNUST, PMB, Kumasi-Ghana. \\ Email:frankfugar@yahoo.com
}

\begin{abstract}
This paper examines the underlying factors behind contractor selection in Ghana in terms of policy and practice. The paper relied on quantitative data with 199 respondents of consultants and clients of construction projects. Using factor analysis, five (5) factors emerged; managerial capabilities, quality standards, resource availability, duration, project cost and location as the most influential factors. The paper concludes that through the classification and/or reclassification of selection factors, practitioners and professionals would find it easier in using these factors to make very informed decisions in contractor selection for future projects and also help client achieve both economic and social value for money.
\end{abstract}

Keywords: contractor selection, cost, Ghana, social value

DOI: $10.7176 / \mathrm{CER} / 12-7-07$

Publication date:July $31^{\text {st }} 2020$

\subsection{Introduction}

In the last few decades, there has been a steady increase in the range of criteria used for the selection of contractors. However, there has been no commensurate improvement in the success rate of construction projects particularly in many emerging economies. Instead, there have been extensive delays in the planned schedule, cost overruns, serious problems in quality and an increased number of claims and litigation (Latham, 1994). When selection criteria is complex, it could lead to low patronage of contractors, with low patronage of contractors, the clients lose out in achieving value for money because of lack of real competition. Again, there are rampant delays and abandonment of projects which negate the attainment of "value-for-money". Some of these delays are sometimes contractor-related which are due to inexperience of contractors among other factors. Procurement of building works involves the selection of contractors through effective evaluation. It is a very important aspect of contract administration which if not carefully undertaken could adversely affect contract execution. It is therefore important that such responsibility of contractor selection be carried out with careful thought and consideration.

Contractor selection is one of the main activities and decisions made by clients. Without a proper and accurate guide for selecting the most appropriate contractor, the performance of the project will be affected and deny client of both economic and social value for money (Cheng \& Heng, 2004). To ensure that the project can be completed successfully, client must select the most appropriate contractor. In this regard, Hatush (1996) and Hatush \& Skitmore (1997) suggust that and efficient procurement system is a system that comprises of five common process elements; project packaging, invitation, pre-qualification, short-listing and bid evaluation. Of utmost importance is the selection of the most suitable contractor to avert project implementation failure due to the contractor's inability to undertake or complete the work. Therefore, a uniform set of guidelines in selecting a contractor is essential to ensure that pricing and background of all bidders are thoroughly assessed and the best selected for award to ensure the successful implementation of the project (Farida, 2007).

In most studies of contractor selection, selection criteria are assumed to be independent of each other. Apparently, these criteria are likely to affect each other. For instance, Fong \& Chio (2000) used a sample of 13 respondents to identify and prioritize eight 'un-correlated' criteria which are tender price, financial capability, past performance, past experience, resources, current workload, past relationship and safety performance for contractor selection. They indicated that, the eight criteria are interrelated to a certain extent. For example, good past experience may lead to good safety performance if the past experience includes good safety records. Good past performance and experience is good evidence of successful projects, which in turn results in strong financial capability. Resources and financial capability may be positively correlated. Tender price may be negatively related to other criteria. 
Despite the importance of contractor section, little is known about the underlying factors behind contractor selection in Ghana in terms of policy and practice. This study sought to determine the underlying factors in the contractor selection to inform policy and practice in the Ghanaian construction industry. The paper is structured in six sections. Section one is the introduction and section two reviews contractor selection practices in the construction industry. The third section explains the research approach and the use of FA to detect the underlying latent factors that significantly influence contractor selection in Ghana. An exploratory and confirmatory factors analysis, as well as the validity and reliability of the derived factors results, are also discussed in section four. Section five contains the discussions of the results and some policy recommendations. Section six outline the conclusion and implications of the findings in terms of theory, practice and policy.

\subsection{Contractor Selection Practices in the Construction Industry}

According to Kwakye, (1997), the methods of selection of contractors can be described as either by competition or by negotiation. In either case, the decision taken should reflect the client's development aims - i.e. the completion of his or her construction project economically, safely, quickly to the required quality and at a profit. The utility of any procurement method is measured in terms of time/speed, cost, quality and other variables such as certainty, flexibility of the method to accommodate unforeseen but important design changes without a problem, ability to deal with complex projects, the level of risk associated with it and how risk is shared and finally the avoidance of disputes (Ernest, 1999).

Anvuur \& Kumaraswamy (2006) concluded in their work that, while the Ghana Procurement Act sets out the legal, institutional and regulatory framework to secure fiscal transparency and public accountability, the sole reliance on traditional contracting and price-based selection limits the scope for the value for money achievable. Expanding the reforms to cover procurement, project delivery methods and strategies, with a focus on 'best value', will increase the potential and likelihood of achieving value for money in public construction in Ghana.

Contractor selection is a major project success factor. Owners, assisted by streamlined guidelines, will be able to clearly identify their requirements and select according to the builder that is qualified to complete the project. This is an issue of extreme importance to the construction industry because a qualified contractor can ensure delivery on time, within budget and meeting the owner's expectations. On the other hand, an inefficient procurement method can result in numerous problems during and subsequent to construction. In addition, contractors' competencies factor is identified as a critical success one. The contractors' financial capabilities, effective implementation of project planning, design and construction within a build environment are crucial elements that should be considered by owners when procuring for a building project. Technical abilities and past experience are also elements of the contractor's competencies that should be part of the evaluation process. As noted, it is essential that the contractor engaged in a building project possesses the appropriate knowledge and ability to manage the project, as it highly impacts the project performance (Chan et al., 2001). The outcome of evaluation determines the selection.

A study conducted within the U.K. construction industry indicated that some of the current practices for contractor selection are characterized by major weaknesses. Usually, cost is the decisive factor based on which the contractor is selected. Contractors' capabilities to deliver a project on time, within budget and satisfactorily complying with requirements are not highly considered during the contractor selection process. Although the reasoning behind the competitive approach is to allow free market competition, which results in better value for the owner's money, this competitive approach sometimes leads to the acceptance of the lowest cost non-competent contractor (Marwa, 2003).

Researchers including Holt, et al. (1994), Herbsman \& Ellis (1992), Merna \& Smith(1990) and Moore(1985) have indicated that the practices and procedures for selecting contractors and awarding contracts in the construction industry are based on those used in the public sector, and these involve systems of bid evaluation dominated by the principle of acceptance of the lowest evaluated price (Skibniewski \& Russell, 1988, Nguyen, 1985).

It is now believed that the public sector system of bid evaluation, concentrating as it does solely on bid price, is one of the major causes of project delivery problems (Holt, et al., 1994), Ellis \& Herbsman, 1991, and Bower, 1989). Contractors, when faced with a shortage of work, are more likely to enter low bids simply to stay in business in the short term and with the hope of somehow raising additional income through 'claims' or cutting costs to compensate (Hatush \& Skitmore, 1998). From a client's point of view, such contractors are risky. This implies also that the automatic selection of the lowest bidding contractor is also risky - a fact that is seldom appreciated by construction clients. 
This process however, will not be easy to change. Most clients, especially those in the public sector, necessarily have to be accountable for their decisions and this becomes more difficult when selecting bidders other than the bidder with the lowest evaluated price. This has led researchers to look for techniques for contractor selection which utilizes information concerning client objectives and contractor capabilities as well as bid price as objectively and transparently as possible as a means of achieving the best value for money (Hatush \& Skitmore, 1998).

"In the last two decades, there has been a steady increase in the range of methods used for the procurement of construction work. Despite this, however, there has been no commensurate improvement in the 'success' rate of construction projects. Instead, there have been extensive delays in the planned schedule, cost overruns, serious problems in quality and an increased number of claims and litigation" (Latham, 1994). By far, the most frequently used method of selecting construction contractors is by competitive bidding, in which the lowest evaluated bidder is awarded the contract (Hatush \& Skitmore, 1997).

Research has significantly improved the contractor selection process in the construction industry. However, some of the proposed methods and approaches could be complex and difficult to apply in practice. The construction industry needs simple but effective methods in contractor selection process due to the limited time intervals of the bidding periods. It should be noted that the stakeholders must adjust the attributes depending on the demand of each project. The critical point is that the selected attributes should have a direct effect on performance. In addition, the selected evaluation attributes should also be based on the measurement culture of the stakeholder.

\subsection{Research Approach}

Architectural, Engineering and Quantity Surveying practitioners in Ghana and also based in the Greater Accra region are used in this study. Greater Accra is chosen because it has a high concentration of consultancy firms among all the regions in Ghana. A mixed approach was used for sampling because of the numbers of each group required for the consultants and the nature of client institutions. A simple random sampling method was adopted for the architects and census for both Engineers and Quantity Surveyors. The clients were selected from a preliminary survey and those that were routinely involved in construction and also have in-house project management units were included in the survey.

A set of variables were selected from literature and respondents asked to rank their importance on a scale of 1-5 with 1 representing not important, 2- slightly important, 3- important, 4- very important and 5- extremely important. The scores were analyzed in determining that the variables considered by respondents in this research have common underlying factors. Questionnaires were sent to consulting firms and clients involved in construction in Ghana based in the Greater Accra region. On the whole, a total of 297 questionnaires, for both clients and consultants, were distributed and 127 were returned, properly filled. That gives a response rate of 42.76 as shown in Table 1.

Table 1: Number of Questionnaires Issued and Response Rate

\begin{tabular}{|l|l|l|l|}
\hline Institutions & Number Issued & Number Returned & Percentage (\%) \\
\hline Clients & 30 & 19 & 63.33 \\
\hline Architecture & 127 & 38 & 29.92 \\
\hline Q. Surveying & 49 & 33 & 67.35 \\
\hline Engineering & 91 & 37 & 40.66 \\
\hline Total & 297 & 127 & 42.76 \\
\hline
\end{tabular}

Fieldwork, 2016

\subsection{Data Analysis}

Construction professionals were asked to rank the importance of the 67 variables listed from literature as variables considered in selecting contractors, according to their opinion. The rankings of the 127 received responses were entered into SPSS and analyzed.

\subsection{Reliability Tests}

The Cronbach's alpha of 0.977 (Table 2) obtained for this test indicate that the question was measuring the same construct in the study. 
Table 2: Cronbach's Alpha Test

\begin{tabular}{|l|l|}
\hline Cronbach's Alpha & N of Items \\
\hline .977 & 67 \\
\hline
\end{tabular}

Table 3 below shows the KMO measure of sampling adequacy and Bartlett's test of sphericity.

Table 3: KMO and Bartlett's Test

\begin{tabular}{|l|l|l|}
\hline \multicolumn{2}{|l|}{ Kaiser-Meyer-Olkin Measure of Sampling Adequacy. } & .868 \\
\hline Bartlett's Test of Sphericity & Approx. Chi-Square & 7452,892 \\
\hline & df & 2211 \\
\hline & Sig. & .000 \\
\hline
\end{tabular}

From table 3 above the overall KMO measure of 0.868 for the data indicate that it is reasonable to go ahead with the factor analysis. The Bartlett's Test of Sphericity significance level of 0.00 from table 3 above indicates that the data is suitable for factor analysis and that there is significant relationship between the variables. The method used for extracting the factors is the principal component analysis where linear combinations of observed variables are formed. The first principal component (factor) is the combination that account for largest amount of variance and the second principal component (factor) account for the next largest amount of variance and is uncorrelated with the first. As many components as there are variables are first extracted as shown in table 4 below.

\subsection{Factors Extracted}

In the Total column, under the initial eigenvalue column (Table 4) there are the total variances explained by each factor. The column labeled \% of variance is the percentage of total variance attributable to each factor. Example, factor 1 has total variance of 28,551, which is $42.613 \%$ of the total variance of the 67 factors; factor 2 has total variance of 3,438 , which is $5.131 \%$ of the total variance of the 67 factors. The Cumulative $\%$ column is the sum of the percentage variances for that factor and the factors that precede it in the table. From Table 4 it is seen that about $52 \%$ of the total variance is explained by the first three factors. The factors are arranged in decreasing order of total variance explained.

The eigenvalue-greater-than-two criterion, suggesting that only factors that account for variances greater than two should be included in the factor extraction, was applied in the factor extraction. This works best for this solution because individual variables have variance of 1, using eigenvalue-greater-than-one would have resulted in 13 factors being extracted which would have been high considering that the aim is to extract as few as possible factors. The convention of component matrix coefficients greater than 0.50 to be shown was adopted. As a result, only factor scores greater than 0.50 are shown on component matrix in table 5 and the rotated component matrix in table 6 .

\subsection{Rotation}

From the component matrix, Table 5, it could be seen that some of the variables are more highly correlated with some factors than others. In order to make it easier to assign meaning to the factors, it is ideal to see groups of variables with large coefficients for one factor and small coefficients for the others. The component matrix is therefore rotated to achieve simple structure, where each factor has large loadings in absolute value for only some of the variables, making it easier to identify. Table 6 shows the rotated component matrix after varimax rotation and after the variables has been sorted by the absolute values of the loadings. To make it easier to identify factors, the display of small coefficients (less than .5) was suppressed. In tables 5 and 6 correlations less than 0.5 are not shown. Five (5) sets of variables are seen in table 6 . Twenty-three variables are highly correlated to factor 1 , fifteen, three, five and five variables correlate highly with factors $2,3,4$ and 5 in that order.

\subsubsection{Discussions of Results}

The 67 contractor selection variables in this study were designed to find those among them that correlate highly with each other. This was distributed to 297 construction professionals and 127 were returned. A factor analysis (principal component analysis) with varimax rotation was used to investigate how these variables correlate with each other and for that matter see how the variables can be reduced to a smaller number of factors that can represent the variables. The eigenvalues produced in the extraction were examined on the total variance explained table with the following results; 5 factors, representing about $59 \%$ of the variables' variance, were extracted to represent 51 out of the 67 variables. The 5 factors with eigenvalues greater than two are reported here. Factor loadings, after varimax rotation is shown in Table 6 as the rotated component matrix table. 
Table 4: Total Variance Explained

\begin{tabular}{|c|c|c|c|c|c|c|c|c|c|}
\hline Component & Initial $\mathrm{E}$ & values & & Extract & Ims of Squ & d Loadings & Rotatio & Sums of Sq & red Loadings \\
\hline & Total & $\begin{array}{l}\% \text { of } \\
\text { Variance }\end{array}$ & $\begin{array}{l}\text { Cumulative } \\
\%\end{array}$ & Total & $\begin{array}{l}\% \text { of } \\
\text { Variance }\end{array}$ & Cumulative \% & Total & $\begin{array}{l}\% \text { of } \\
\text { Variance }\end{array}$ & Cumulative \% \\
\hline 1 & 28,551 & 42,613 & 42,613 & 28,551 & 42,613 & 42,613 & 15,296 & 22,830 & 22,830 \\
\hline 2 & 3,438 & 5,131 & 47,744 & 3,438 & 5,131 & 47,744 & 10,454 & 15,603 & 38,433 \\
\hline 3 & 2,815 & 4,202 & 51,946 & 2,815 & 4,202 & 51,946 & 5,181 & 7,733 & 46,166 \\
\hline 4 & 2,544 & 3,797 & 55,743 & 2,544 & 3,797 & 55,743 & 4,317 & 6,444 & 52,610 \\
\hline 5 & 2,207 & 3,294 & 59,037 & 2,207 & 3,294 & 59,037 & 4,306 & 6,428 & 59,037 \\
\hline 6 & 1,910 & 2,850 & 61,887 & & & & & & \\
\hline 7 & 1,798 & 2,683 & 64,571 & & & & & & \\
\hline 8 & 1,500 & 2,239 & 66,809 & & & & & & \\
\hline 9 & 1,414 & 2,111 & 68,920 & & & & & & \\
\hline 10 & 1,351 & 2,016 & 70,936 & & & & & & \\
\hline 11 & 1,266 & 1,889 & 72,825 & & & & & & \\
\hline 12 & 1,208 & 1,804 & 74,629 & & & & & & \\
\hline 13 & 1,079 & 1,610 & 76,239 & & & & & & \\
\hline 14 & 989 & 1,476 & 77,715 & & & & & & \\
\hline 15 & 957 & 1,428 & 79,143 & & & & & & \\
\hline 16 & ,868 & 1,295 & 80,438 & & & & & & \\
\hline 17 & 809 & 1,208 & 81,646 & & & & & & \\
\hline 18 & ,760 & 1,134 & 82,780 & & & & & & \\
\hline 19 & ,708 & 1,057 & 83,837 & & & & & & \\
\hline 20 & ,650 & ,970 & 84,808 & & & & & & \\
\hline 21 & ,623 & 930 & 85,738 & & & & & & \\
\hline 22 & 605 & 902 & 86,640 & & & & & & \\
\hline 23 &, 569 & 850 & 87,490 & & & & & & \\
\hline 24 & ,554 & ,826 & 88,316 & & & & & & \\
\hline 25 & ,508 & ,758 & 89,074 & & & & & & \\
\hline 26 & ,485 & ,724 & 89,798 & & & & & & \\
\hline 27 & ,450 & 671 & 90,470 & & & & & & \\
\hline 28 & ,420 & 627 & 91,097 & & & & & & \\
\hline 29 & ,399 & ,595 & 91,692 & & & & & & \\
\hline 30 & ,368 & ,550 & 92,241 & & & & & & \\
\hline 31 & ,348 & ,519 & 92,761 & & & & & & \\
\hline 32 & ,332 & ,495 & 93,255 & & & & & & \\
\hline 33 & 299 & ,446 & 93,702 & & & & & & \\
\hline 34 & 289 & ,431 & 94,132 & & & & & & \\
\hline 35 & ,277 & ,413 & 94,546 & & & & & & \\
\hline 36 & 268 & , 400 & 94,945 & & & & & & \\
\hline 37 & ,250 & ,373 & 95,318 & & & & & & \\
\hline 38 & ,232 & ,347 & 95,665 & & & & & & \\
\hline 39 & ,223 & ,333 & 95,998 & & & & & & \\
\hline 40 & ,209 & ,312 & 96,310 & & & & & & \\
\hline 41 & 201 & ,300 & 96,610 & & & & & & \\
\hline 42 & , 192 & ,287 & 96,897 & & & & & & \\
\hline 43 & , 176 & 263 & 97,160 & & & & & & \\
\hline 44 &, 163 & 244 & 97,404 & & & & & & \\
\hline 45 & ,154 & 230 & 97,633 & & & & & & \\
\hline 46 & , 147 & 219 & 97,852 & & & & & & \\
\hline 47 & 138 & 206 & 98,058 & & & & & & \\
\hline 48 & ,131 & 196 & 98,254 & & & & & & \\
\hline 49 & , 120 & , 179 & 98,433 & & & & & & \\
\hline 50 & , 109 & , 163 & 98,596 & & & & & & \\
\hline 51 & ,108 & 161 & 98,758 & & & & & & \\
\hline 52 & ,096 & , 144 & 98,902 & & & & & & \\
\hline 53 & ,093 & 139 & 99,041 & & & & & & \\
\hline 54 & ,083 & , 124 & 99,165 & & & & & & \\
\hline 55 & ,071 & 106 & 99,271 & & & & & & \\
\hline 56 & ,066 & ,098 & 99,369 & & & & & & \\
\hline 57 & ,062 & ,093 & 99,462 & & & & & & \\
\hline 58 & ,055 & ,082 & 99,544 & & & & & & \\
\hline 59 &, 051 & ,076 & 99,620 & & & & & & \\
\hline 60 & ,048 & ,071 & 99,691 & & & & & & \\
\hline 61 & ,042 & ,062 & 99,753 & & & & & & \\
\hline 62 & ,038 & ,057 & 99,810 & & & & & & \\
\hline 63 & ,038 & ,056 & 99,866 & & & & & & \\
\hline 64 & ,031 & ,046 & 99,913 & & & & & & \\
\hline 65 & ,023 & ,035 & 99,948 & & & & & & \\
\hline 66 &, 020 & 030 & 99,978 & & & & & & \\
\hline 67 &, 015 & 022 & 100,000 & & & & & & \\
\hline
\end{tabular}

Extraction Method: Principal Component Analysis 
Table 5: Component Matrix (a)

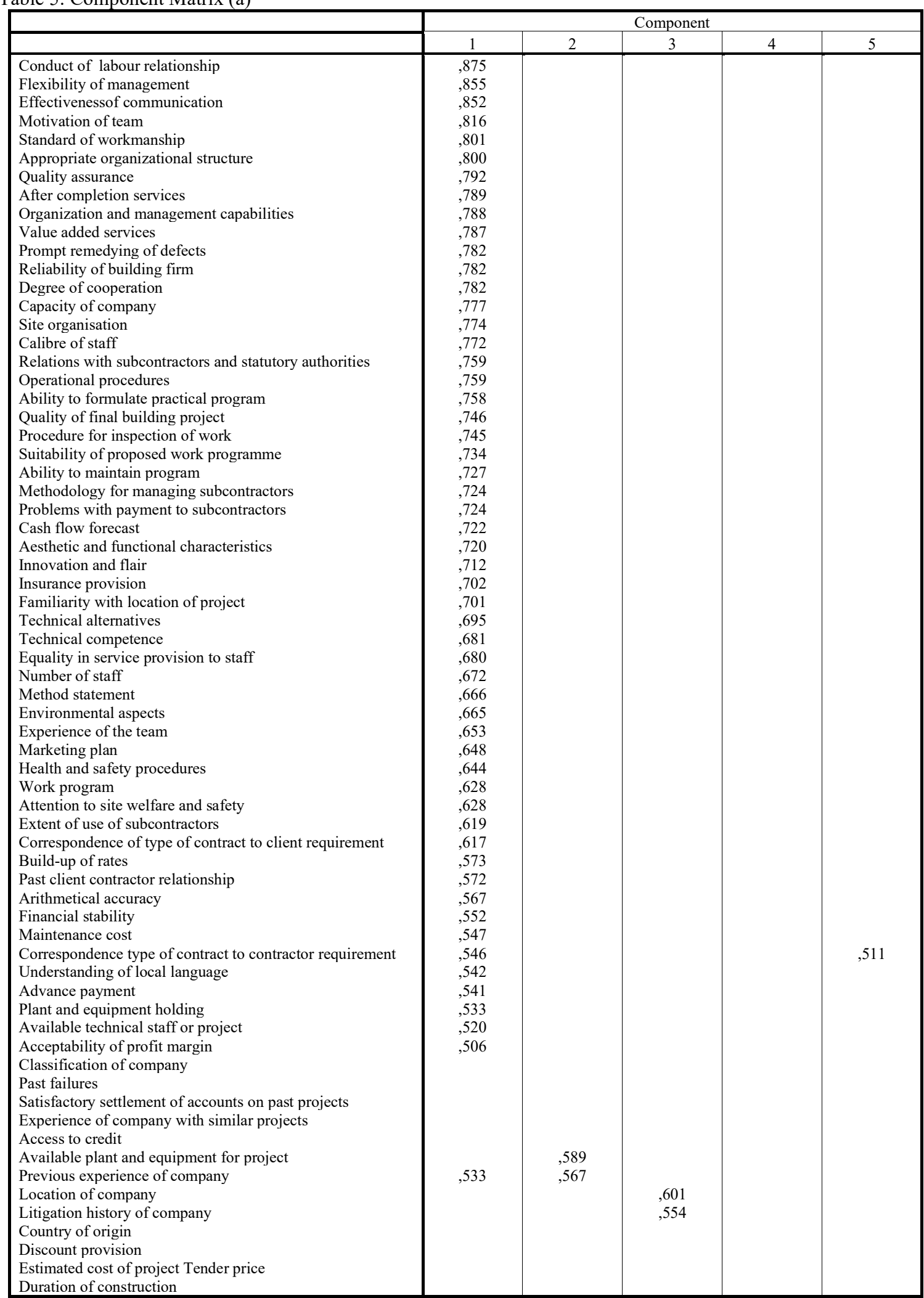

Extraction Method: Principal Component Analysis. A 5 components extracted. 
Table 6: Rotated Component Matrix (a)

\begin{tabular}{|c|c|c|c|c|c|}
\hline & \multicolumn{5}{|c|}{ Component } \\
\hline & 1 & 2 & 3 & 4 & 5 \\
\hline 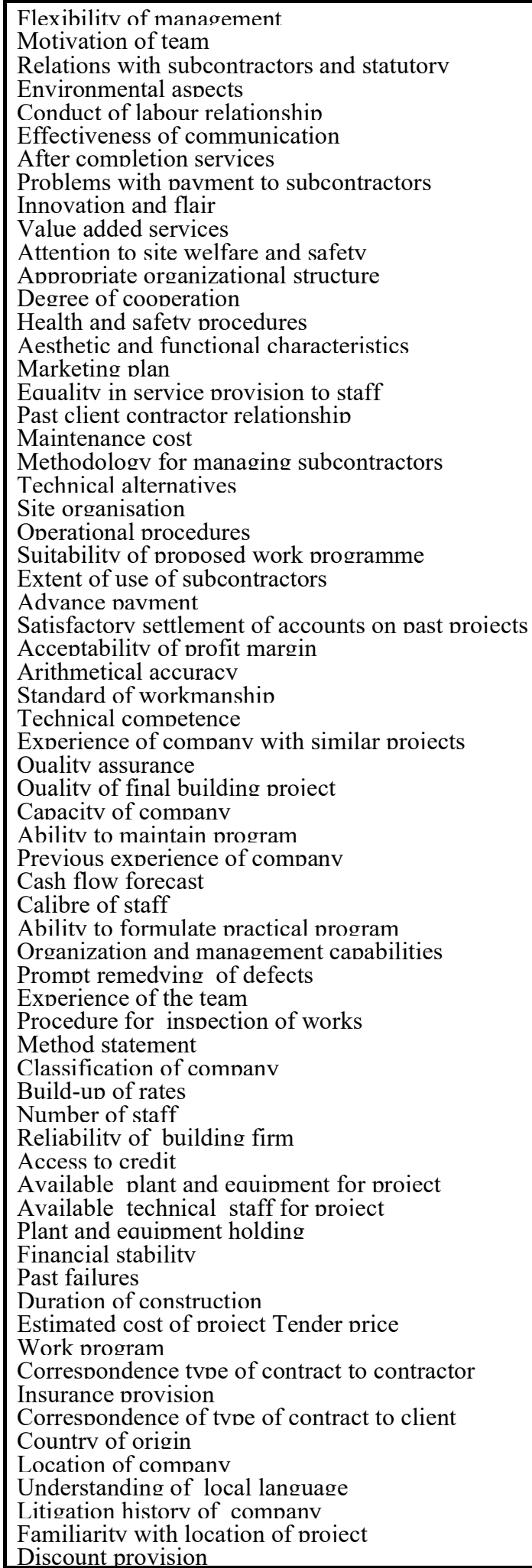 & $\begin{array}{l}.786 \\
.764 \\
.757 \\
.740 \\
.737 \\
.703 \\
.701 \\
.675 \\
.665 \\
.661 \\
.661 \\
.660 \\
.656 \\
.656 \\
.654 \\
.629 \\
.608 \\
.600 \\
.600 \\
.575 \\
.568 \\
.559 \\
.518\end{array}$ & $\begin{array}{l}.694 \\
.691 \\
.651 \\
.643 \\
.637 \\
.630 \\
.622 \\
.596 \\
.586 \\
.582 \\
.563 \\
.561 \\
.551 \\
.515 \\
.512\end{array}$ & $\begin{array}{l}.805 \\
.737 \\
.641\end{array}$ & $\begin{array}{l}.670 \\
.588 \\
.540 \\
.539 \\
.523\end{array}$ & $\begin{array}{l}.709 \\
.686 \\
.650 \\
.636 \\
.624\end{array}$ \\
\hline
\end{tabular}

Rotation Method: Varimax with Kaiser Normalization 
4.4.1.0 Rating of Variables within Factors

Rating of variables within factors were done according to the classification by Comrey \& Lee (1992) as follows; factor loadings of over 0.71 can be considered excellent, 0.63 to 0.70 very good, 0.55 to 0.62 good, 0.45 to 0.54 fair, and 0.32 to 0.44 poor.

\subsubsection{Factor 1: Managerial Factor}

Factor 1 is comprised of 23 of the variables with 5 of them (the first five) loading excellently with 0.71 and above, 11 of them very good with loadings of $0.63-0.70$. The next 6 of the variables were good with loadings of $0.56-$ 0.61 . The last 4 loaded fairly with scores of 0.50-0.52. Factor 1 shared four variables with factor 2 ; these shared variables were allocated to the factors according to where it loaded higher. The 23 extracted variables after rotation with factor loadings (in bracket), were as follows; Flexibility of management (0.786), Motivation of team (0.764), Relations with subcontractors and statutory authorities (0.757), Environmental aspects (0.740), Conduct of labour relationship (0.737), Effectiveness of communication (0.703), After completion services (0.701), Problems with payment to subcontractors $(0.675)$, Innovation and flair $(0.665)$, Value added services $(0.661)$, Attention to site welfare and safety (0.661), Appropriate organizational structure (0.660), Degree of cooperation (0.656), Health and safety procedures (0.656), Aesthetic and functional characteristics (0.654), Marketing plan (0.629), Equality in service provision to staff (0.608), Past client/contractor relationship (0.600), Maintenance cost $(0.600)$, Methodology for managing subcontractors (0.575), Technical alternatives (0.568), Site organization (0.559), Operational procedures (0.518). These set of 23 variables accounted for $22.83 \%$ of the variances, after rotation of the factors (Table 4), and are generally concerned about managerial, environmental and health and safety issues. The importance of managerial factors in construction is confirmed by Stukhart, (1995) that, in order to award and successfully manage effective contracts, organizations must have disciplined, capable, and mature contract management processes in place. This is confirmed by Chan et al., (2001), that it is essential that the contractor engaged in a building project possesses the appropriate knowledge and ability to manage the project, as it highly impacts the project performance.

\subsubsection{Factor 2: Quality and Standards Factor}

Factor 2 comprised of 15 variables, 6 of them loading very good with scores of $0.63-0.69,7$ good with scores of $0.55-0.62$ and the last 3 with fair loadings of $0.50-0.51$. The 15 extracted variables after rotation for factor 2 , with factor loadings, were as follows; Standard of workmanship (0.694), Technical competence (0.691), Experience of company with similar project (0.651), Quality assurance (0.643), Quality of final building project (0.637), Capacity of company (0.630), Ability to maintain program (0.622), Previous experience of company (0.596), Cash flow forecast (0.586), Calibre of staff (0.582), Ability to formulate practical program (0.563), Organization and management capabilities (0.561), Prompt remedying of defects (0.551), Experience of the team (0.515), Procedure for inspection of work $(0.512)$.

Quality management is a critical component in the successful management of construction projects (Hellard, 1995, Abdul-Rahman, 1997, Love, et al., 1999). Odeh and Battaineh, (2002) affirms this when they stated "To improve the present situation, authors suggest different kinds of improvement to the contracts incentive for good quality and awarding capabilities more than just the price".

\subsubsection{Factor 3: Resource Availability Factor}

Factor 3 is comprised of 3 variables with two of them (first two) loadings excellently with 0.71 and above, and the other one very good with a loading of 0.64 . The 3 extracted variables after rotation for factor 3 , with factor loadings, were as follows; Available plant and equipment for project (0.805), Available technical staff for project $(0.737)$, Plant and equipment holding (0.641). Efficient production of building projects depends on the availability of the right resources at the right time. Construction programmes usually define the resources required (information, operatives, staff, materials, plant, sub-contractors' and suppliers' requirements) in terms of time, skill and quantity. The resource requirements of projects must be planned to ensure economic use of expensive resources (CIB, 1991)

\subsubsection{Factor 4: Duration and Cost Factor}

Factor 4 is comprised of 5 variables with the first one rated very good (0.67) the second one rated well and the last three with rating of fair. The 5 extracted variables after rotation for factor 4 , with factor loadings, were as follows; Duration of construction (0.670), Estimated cost of project tender price (0.588), Work program $(0.540)$, Correspondence type of contract or requirement (0.539), Insurance provision (0.523). Construction duration, and thus the speed with which building proceeds, plays an important role in the commercial success of a construction project (Bordoli \& Baldwin, 1998). In this connection, a construction duration that is too long, as well as one that is too short, can have a negative impact on the project's success. 
For this reason, planning the construction duration must be included in addition to cost and quality planning as one of the major tasks of construction project management, particularly since all three areas are closely linked (Nkado, 1995, Walker, 1995). Ellis \& Herbsman, (1991) outlined the importance of time/cost to determine the winning bidder in highway construction contracts, where the criteria to be considered in selection are bid prices and contract time (the road user's cost is applied to the contract time).According to the Charted Institute of Building (CIB, 1991), from commencement to completion of a project, the management of the work involves the control of progress in terms of time, cost, resource and quality.

\subsubsection{Factor 5: Location Factor}

Factor 5 is comprised of 5 variables with 4 of them (first four) loadings very good, and the other one with a loading of 0.62 .The 5 extracted variables after rotation for factor 5 , with factor loadings, were as follows; Country of origin (0.709), Location of company (0.686), Understanding of local language (0.650), Litigation history of company (0.636), Familiarity with location of project (0.624). By location factors in this study is meant contractor selection variables relating to different geographical locations. The effect of different geographical locations on construction projects is so important that researchers use a term 'location factor' to represent its cost implication. According to AACE International Recommended Practice No. 28R-03, "A location factor is an instantaneous (i.e., current-has no escalation or currency exchange projection), overall total project factor for translating the total cost of the project cost elements of a defined construction project scope of work from one geographic location to another. This factor recognizes differences in productivity and costs for labor, engineered equipment, commodities, freight, duties, taxes, procurement, engineering, design, and project administration. The cost of land, scope/design differences for local conditions and codes, and differences in operating philosophies are not included in a location factor". Location factors provide a way to evaluate relative cost differences between two geographic locations (AACE International Recommended Practice No. 28R-03, 2006).

\subsection{Recommendations}

From the analysis and discussions earlier, it is recommended that: These underlying selection criteria should therefore be made known to construction professionals to help select 'best' contractors for clients to achieve project objectives through seminars and conferences by stakeholders. With the Government of Ghana being a major player in the Ghanaian construction industry, it should study into the selection criteria that relate to the under-listed (1-5 factors) and implement their adoption by public procurement entities. And prioritise them among the criteria used in selection, managerial, standards and quality, resource availability, time and cost, and location factors

\subsection{Conclusion}

Contractor selection is a vital task for a client to have his project completed within budget, on schedule and with good quality. The goal of identifying the underlying factors for contractor selection is to enable the selection of the "best" contractor by the client from the set of available options through the assessment of contractor"s capabilities on those factors. In the opinion of researchers such as Nerija \& Audrius, (2006), this could help avert construction project problems such as projects behind schedule, project cost overruns and inappropriate quality associated to be a direct outcome of the selection of an inadequate contractor.

Using factor analysis, it was determined that there were common underlying factors among the 67 contractor selection variables which were reduced to five common factors making up 59\% of the variances of all the variables. It is prudent therefore, that these most important factors be considered when selecting a contractor likely to perform to the satisfaction of the client on construction projects. Selecting the best contractor is a complex decision process for construction professionals. It requires a large number of variables to be simultaneously measured and/or evaluated. Many of these variables are related to one another in a complex way. Selection variables very often conflict insofar as improvement in one often results in decline of another (Sonmez, et al., 2001). It is important that the project does not fail due to the contractor's inability to undertake or complete the works. Therefore, a uniform set of guideline in selecting a contractor is essential to ensure that price, experience and technical ability of the bidder is thoroughly assessed. The selected contractor for award should be capable of ensuring the successful implementation of the project.

The variables used in evaluation and selection of contractors are many and often have common underlying factors. This study sought to find those variables that have common underlying factors according to the opinion of construction professionals in Ghana using Factor analysis. Within the aims and objectives set out in this study to find from the opinion of Ghanaian construction professionals the significant factors considered in selecting contractors, the following conclusion can be drawn from the analysis observed. 
Most respondents are of the opinion that contractors' selection can affect the time of delivery, cost of project and the quality of final building product. Most of the variables used in selecting contractors have common underlying factors and therefore correlate very well with each other. As a result the 67 variables used in this study was reduced to five common factors which represents $59 \%$ of the variances of the variables. The common factors were named; managerial factors, standards and quality factors, resource availability factors, Time and Cost factors and location factors.

\subsection{References}

AACE International Recommended Practice No. 28R-03, 2., 2006. Developing Location Factors By Factoring As Applied in Architecture and Engineering,. s.1.:s.n.

Abdul-Rahman, H., 1997. Some observations on the issues of quality cost in construction.. International Journal of Quality and Reliability Management, 14(5), pp. 464-481.

Ang, G., Grooseman, M. \& Scholten, N., 2005. Dutch performance-based approach to building regulations and public procurement.. Business Research and Information, 33(2), pp. 107-119.

Anvuur, A. \& Kumaraswamy, M., 2006. Taking Forward Public Procurement Reforms in Ghana. CIB W107 Construction in Developing Economies International Symposium "Construction in Developing Economies: New Issues and Challenges", 18th - 20th January.

Bordoli, D. \& Baldwin, A., 1998. "A methodology for assessing construction project delays". Construction Management and Economics, 16(3), pp. 327-337.

Bower, D., 1989. Innovative Contracting Practice, Proc., ASCE, Highway Conf., ASCE. New York,NY: s.n.

Chan, A., Ho, D. \& Tam, C., 2001. "Design and Build Project success factors: Multivariate analysis.". Journal of Construction Engineering and Management, ASCE,, 127(2), pp. 93-100.

Cheng, E. W. \& Heng, L., 2004. Contractor Selection Using the Analytic Network Process. Management and Economics, Issue ISSN 0144-6193 print/ISSN 1466 433X online.

Chris, D., 2004. Statistical Methods for Organiztional Research, Theory and Practice. New York (Routledge, Madison Ave.): s.n.

CIB, 1991. 'Planning and Programming in Construction: a guide to good practice'. The Charted Institute of Building, December.

Comrey, A. L. \& Lee, H. B. (1992), A First Course in Factor Analysis. Hillsdale, NJ, Erlbaum.

Ellis , R. and Herbsman, Z., 1991. Cost-time bidding concept: an innovative approach. Transportation Reseaarch Record 1282, pp. 89-94.

Ernest, O.-T., 1999. Construction Procurement Decision in Ghana,. MSc Thesis, Department of Building Technology, U.S.T.

Farida, M. H., 2007. Contractor's perception of the Use of Statistical Approach in the Tender Evaluation at the Public Works Department,. American Journal of Applied Sciences, 12(4), pp. 1084-1089.

Fong, P. S. \& Chio, S. K., 2000. 'Final Contractor Selection using the analytical hierarchyprocess'. Construction Management and Economics, Volume 18, pp. 547-557.

Hatush , Z. \& Skitmore, M., 1997. 'Criteria for Contractor Selection'. Construction Management and Economics, 15(1), pp. 19-38.

Hatush, Z. \& Skitmore, M. R., 1998. Contractor Selection using multi-criteria utility theory: $\quad$ an additive model. 33(2-3), pp. 105-115.

Hatush, Z., 1996. 'Contractor Selection: Using multi-attribute utility theory, unpublished thesis.. (Department of Surveying, University of Salford.).

Hellard, R., 1995. Project Paternering : Principle and Prctice.

Herbsman, Z. \& Ellis, R., 1992. Multiparameter bidding system innovation in contract administration,. Journal of Construction Engineering and Management, 118(1), pp. 142-150.

Holt, D. G., Paul, O. O. \& Frank, C. H., 1994. Factors influencing U.K construction clients' choice of Contractor. Building and Environment. 29(2), pp. 241-248.

Holt, G. D., 1996. 'Applying Cluster Analysis to construction Contractor Classification'. Building And Environment, 31(6), pp. 557-568.

Kwakye, A. A., 1997. Construction Project Administration in Practice.. s.1.:Addison Wesley Longman Limited.

Latham, M., 1994. Constructing the team, Final Report of the Government/Industry Review of Procurement and Vontractual Arrangements in the UK Construction Industry, HMSO. July.

Love, P., Li, H. \& Mandal, P., 1999. Rework: a symptom of a dysfunctional supply-chain.. $\quad$ European Journal of Purchasing and Suppl Management, 5(1), pp. 1-11.

Marija, J., 2003. SPSS 12.0 Statistical Procedures Comparison. Upper Saddle River: Prentice Hall. 
Marwa, E.-W., 2003. Evaluating Design-Build Procurement Methods, Msc Thesis, College of Engineering, Department of Architectural Engineering.. The Pennsylvania State University: s.n.

Merna, A. \& Smith, N., 1990. Bid Evaluation for UK public sector construction contracts. Inst. Civil Engineers, 1 February.pp. 91-105.

Moore, M., 1985. Selecting a contractor for fast-track projects, Pt III. In: Quantitative Plant Engineering. s.1.:s.n., pp. 54-60.

Nerija, B. \& Audrius, B., 2006. Analysis of Criteria For Contractors' Qualification Construction Economics and Property Management,. Vilnius Gediminas Sauletekio al. 11, LT-10223 Vilnius: s.n.

Ng, S. T. \& Skitmore, R., 1999. Client and consultant perspectives of pre-qualification criteria.. Building Environment, 34(5), pp. 607-621.

Nguyen, V., 1985. Tender Evaluation by Fuzzy Sets. Journal of Construction Engineering and Management, 111(3), pp. 231-243.

Nkado, R., 1995. "Construction time-influencing factors: the contractor's perspedtive".. Construction Management and Economics, 13(1), pp. 81-90.

Odeh, A. \& Battaineh, H., 2002. Causes of Construction Delay: Traditional Contracts. International Journal of Project Management, 20(1), pp. 67-73.

Palaneeswaran, E. \& Kumaraswamy, M. M., 2001. Recent Advances and proposed improvements in contractor pre-qualification methodologies.. Building and Environment, 36(1), pp. 73-87.

Public Procurement Act, 2003. Act 663. Ghana

Russell , J., Hancher, D. \& Skibniewski, M., 1992. Contractor Pre-Qualification data for construction owners.. Construction Management and Economics, 10(2), pp. 117-135.

Skibniewski, M. \& Russell, J., 1988. Decision Criteria in Contractor pre-qualification. Journal of Management in Engineering, ASCE, 1 April, 4(2), pp. 48-64.

Sonmez, M., Yang, J. \& Holt, G., 2001. Addressing the contractor selection problem using an evidential reasoning approach,. In: Engineering, Construction and Architectural Management 8/3. s.1.:Blackwell Science Limited, pp. 198-210.

Stukhart, G., 1995. Construction Materials Management. Marcel Dekker Inc..

Walker, D., 1995. "An investigation into construction time performance". Construction Management and Economics, 13(2), pp. 263-274. 